\title{
The Symbol of Bed (Thalamus) in Images of the Annunciation of the 14th-15th Centuries in the Light of Latin Patristics
}

\author{
José María Salvador-González* \\ Professor of Art History, Faculty of Geography and History, Complutense University of Madrid, Spain \\ *Corresponding Author: José María Salvador-González, Professor of Art History, Faculty of Geography \\ and History, Complutense University of Madrid, Spain
}

\begin{abstract}
This article attempts to interpret the doctrinal meanings hidden under the bed symbol in some images of the Annunciation of the 14th and 15th centuries. For this purpose, thirteen Annunciations of this period which include that piece of furniture are analyzed, and in passing some inadequate interpretations that have been given about any of these pictorial images are evidenced. To justify our interpretations, we rely on an abundant corpus of texts through which many Fathers and theologians of the Latin Church consider the thalamus concept as an eloquent metaphor for the incarnation of the Son of God as a man in the Virgin Mary's womb, as well as for her virginal divine maternity.
\end{abstract}

Keywords: Christian Iconography - Medieval Art - Annunciation - Christ's Incarnation.

The increasingly complex and detailed images of the Annunciation of the 14th and 15th centuries include almost always some narrative details -such as a stem of lilies, ${ }^{1}$ a book of prayers, a house in the form of a temple, ${ }^{2}$ the divine ray of light descending, with the dove of the Holy Spirit, towards the Mary's ear, ${ }^{3}$ or the submissive and demure attitude of the Virgin Mary ${ }^{4}$, whose respective symbolism has been highlighted, with greater or lesser success, by numerous experts. These latemedieval Annunciations also incorporate very frequently a bed, a detail that, on the contrary, has not deserved so much attention by the specialists. In fact, this bed has gone unnoticed by many art historians and, when some of them mention it, they either consider it a mere compositional or decorative detail with no significant value, or interpret its meaning gratuitously without any documentary basis.

For this reason, this article proposes three complementary aims: a) first, to present a select set of pictorial images of the Annunciation of the 14th and 15th centuries that include a bed in their

\footnotetext{
${ }^{1}$ We have studied the symbolic meaning of the stem of lilies in the Annunciations of the 14th and 15th centuries in the following works: J.M. Salvador-González (2013). "Flos de radice Iesse. A hermeneutic approach to the theme of the lily in the Spanish Gothic painting of The Annunciation from patristic and theological sources". Eikón Imago, 4: 183-222; J.M. Salvador-González (2014a). "In virga Aaron Maria ostendebatur. Nueva interpretación del lirio en La Anunciación gótica española a la luz de fuentes patrísticas y teológicas", Anales de Historia del Arte, 24, 37-60; J.M. Salvador-González (2014b), "Flos campi et lilium convallium. Third interpretation of lily in the iconography of The Annunciation in Italian Trecento art from patristic and theological sources", Eikón Imago, 5, 75-96; J.M. Salvador-González (2015c), "Sanctitate vernans virga Aaronis. Interpretation of the stem of lilies in the medieval iconography of the Annunciation according to theological sources". Oxford Academic Studies Press. Art Studies and Architectural Journal, vol. 10, \# 9, 2-32.

${ }^{2}$ We have analyzed the symbolism of the house in the form of a temple in the paper: J.M. Salvador-González 12019b). "Iconographic interpretation of the temple as a theological symbol in images of the Annunciation of the 14 th and 15th centuries" (article under evaluation in an academic journal).

${ }^{3}$ We have dealt with this symbolic detail in J.M. Salvador-González (2015b). "Per aurem intrat Christus in Mariam. Aproximación iconográfica a la conceptio per aurem en la pintura italiana del Trecento desde fuentes patrísticas y teológicas”. Ilu. Revista de Ciencias de las Religiones, 20, 193-230.

${ }^{4}$ We have interpreted this attitude of Mary in the following works: J.M. Salvador-González (2012). Ancilla et Regina. Aproximaciones a la iconografía mariana en la Edad Media, Saarbrücken: Editorial Académica Española; J.M. Salvador-González (2015a). "The Virgin Mary as a model of obedience in the patristic tradition and her representation in the late medieval iconography of the Annunciation", Oxford Academic Studies Press. Social Sciences and Humanities Journal, vol. 10, \# 8, 2-23.
} 
scenography; b) also, to highlight the silence of many historians in front of that bed and, above all, to stress some unacceptable "interpretations" that have been given about the meaning of this piece of furniture; c) third, and above all, to highlight the dogmatic meaning of the bed in these images of the Annunciation, founded on an abundant corpus of doctrinal texts offered in this regard by many prestigious Fathers and theologians of the Latin Church.

For the rest, this first article is complemented by another, in which we interpret this same symbolic meaning of the bed in other late-medieval representations of the Annunciation in the light of the Fathers of the Greek-Eastern Church. ${ }^{5}$

\section{THIRTEEN IMAges OF THE ANNUNCIATION WiTH BED IN THE 14TH-15TH CENTURIES AND SOME INAPPROPRIATE "INTERPRETATIONS"}

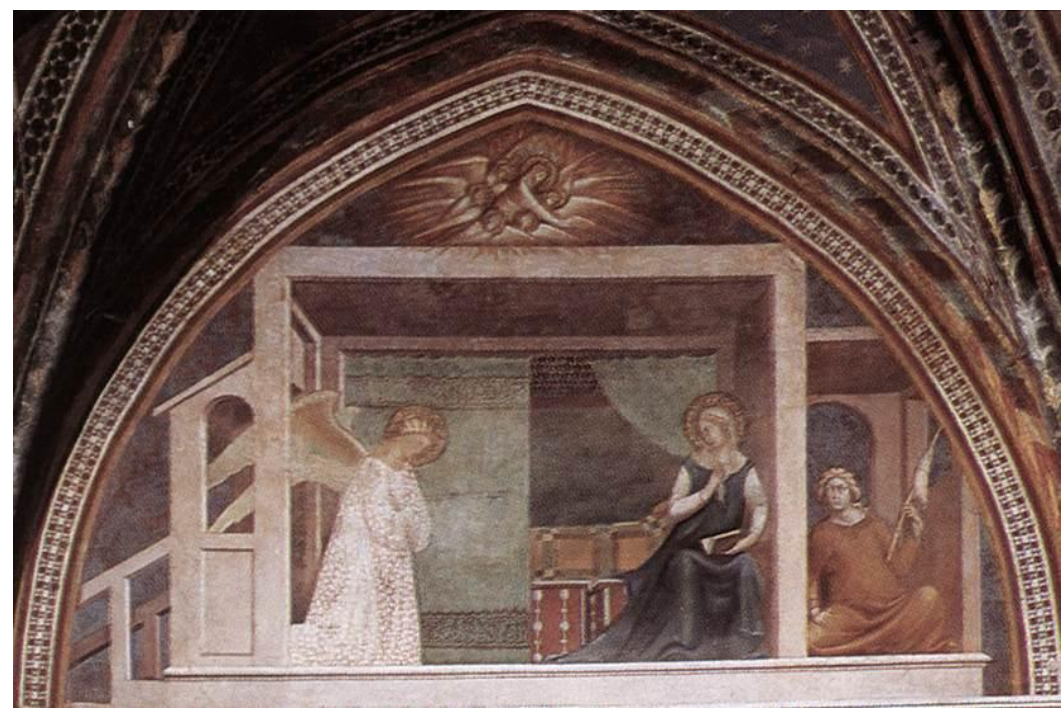

Plate1: Barna da Siena (or Lippo Memmi), The Annunciation, c. 1340. Collegiata di Santa Maria Assunta, San Gimigniano. Photo Wikimedia Commons:

https://commons.wikimedia.org/wiki/File:Barna_Da_Siena_-_The_Annunciation_-_WGA01280.jpg

(Last access: 13/11/2019)

In The Annunciation, which Barna da Siena (or, according to other historians, Lippo Memmi) painted in fresco around 1340 in the Collegiata di Santa Maria Assunta in San Gimigniano (Plate 1), the house of the Virgin Mary in Nazareth -where the Annunciation supposedly happened - appears reduced to a simple and stripped room. It is preceded, to the left of the scene, by a porch with a staircase (from where the archangel Gabriel entered), which on the right is counterbalanced with soft "symmetry" through a narrow room in which a maid spins the wool with a spindle.

Leaving aside the extreme geometric simplification of the scene and the suggestive anecdote of the spinner who, approaching her ear to the dividing wall, spies the dialogue that takes place in the main room, the important element in this image is the sleeping room located at background, through whose curtains (one of them open and wavy) the bed of Mary is clearly perceived. It is very evident that, by placing this bed with such outstanding prominence -as the only piece of furniture of the scenery (except the small table next to the Virgin), occupying the entire background space, in a central position and as a link between Gabriel and Mary-, the intellectual author of this fresco wanted to highlight the significant relevance of this bed. ${ }^{6}$

As Barna da Siena did in the precedent fresco, Giovanni del Biondo also proposes in The Annunciation of the central panel of the Polyptych of The Annunciation, c. 1380-1385, at the Galleria dell'Accademia in Florence (Plate 2), a similar narrative / compositional approach. At the back of the

\footnotetext{
${ }^{5}$ See J.M. Salvador-González (2019b), "The bed in images of the Annunciation of the 14th and 15th centuries as a doctrinal symbol in the light of Greek Patristics" (article under evaluation in an academic journal).

${ }^{6}$ Dealing with this fresco, Joachim Poeschke (2003. Fresques italiennes du temps de Giotto, 1280-1400. Paris: Citadelles \& Mazenod, 2003), is content just to say regarding our subject: "Derrière elle [Mary], une tenture à moitié ouverte laisse apercevoir sa chambre." (Poeschke 2003, 312).
} 

Latin Patristics

room where Mary is sitting, you can see a bed covered with a red quilt between the ajar curtains. Because of its clear emphasis, in a central place at the bottom of the scene and as a link between the angel and the Virgin, this bed seems to have some relevant meaning.

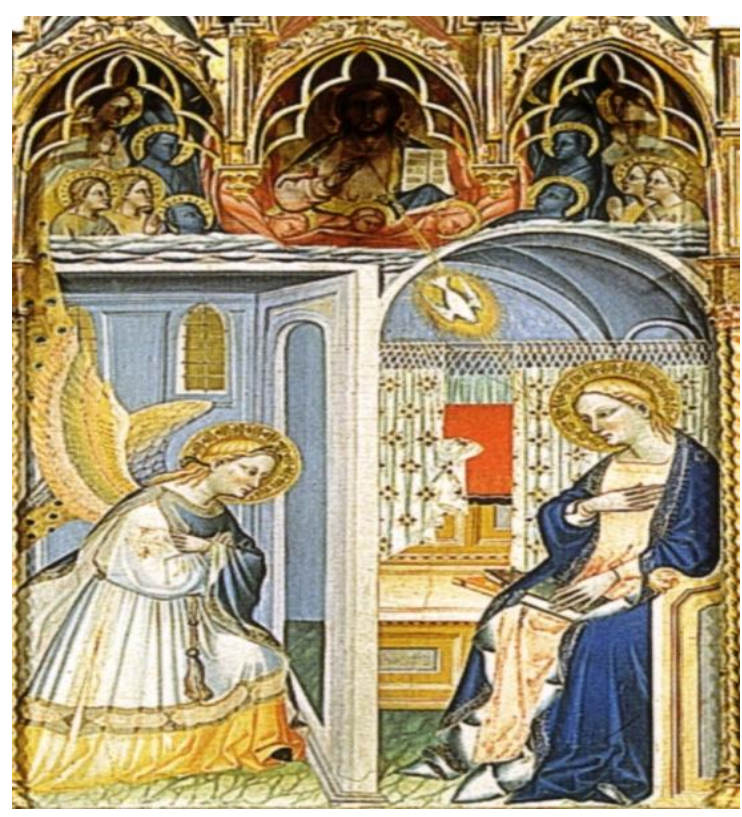

Plate2:Giovanni del Biondo, The Annunciation, central panel of the Polittico dell'Annunciazione, c. 1380-1385, Galleria dell'Accademia, Florence. Photo Wikimedia Commons:

https://it.wikipedia.org/wiki/Polittico_con_1\%27Annunciazione_e_santi\#/media/File:Giovanni_del_biondo,_pol ittico_dell'annunciazione.jpg (Last access: 13/11/2019)

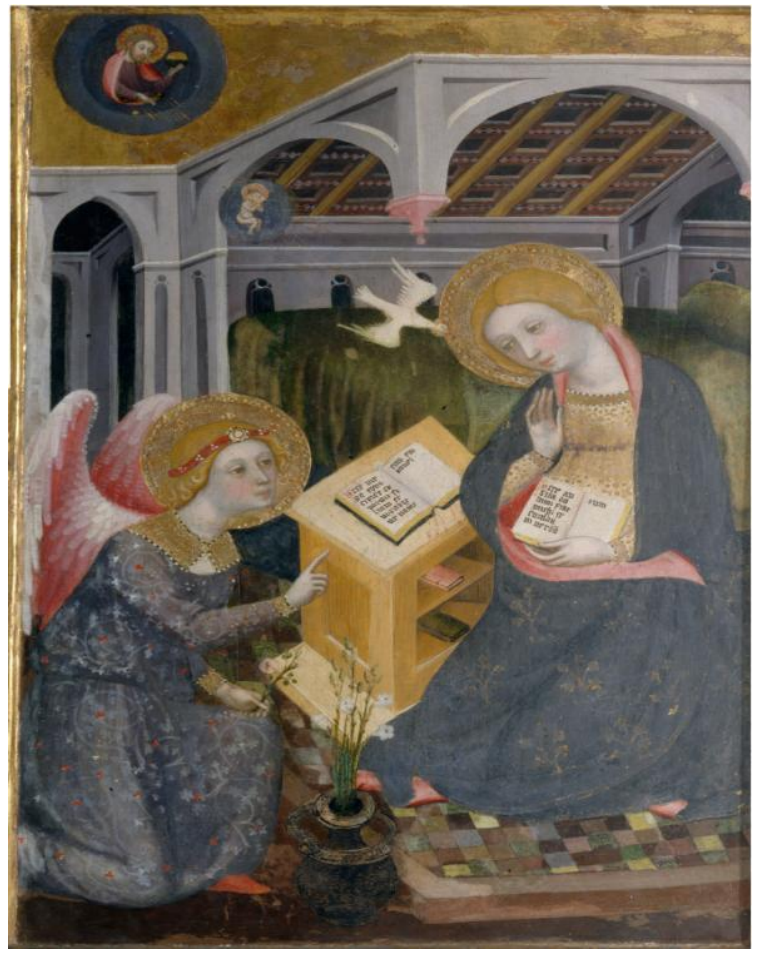

Plate3: Pere Serra, The Annunciation, c.1400-1405. Pinacoteca di Brera, Milan. Photo: Wikimedia Commons https: //commons.wikimedia.org/wiki/File:La_Anunciaci\%C3\%B3n,_por_Pere_Serra.jpg (Last asccess: 09/11/ 20199).

Pere Serra (active in Catalonia between 1357 and 1406) gives the bed an even greater importance in his Annunciation, c. 1400-1405, in the Pinacoteca di Brera in Milan (Plate 3). Within the framework of a house of capricious linear perspective, the angel Gabriel kneels before the seated Mary, who bows her head submissively, to signify her unrestricted obedience of "slave of the Lord" to the divine 

Latin Patristics

design communicated by the heavenly messenger. That submission is made visible through the sentence written in the book that the Virgin holds open, in which you can read her definitive answer to the will of the Most High: "Ecce ansilla [sic] Domini Fiat michi [sic] secundum verbum tu[u]m". The other book that Mary keeps open on the table reads Isaiah's prophecy "Ecce virgo conscipiet [sic] et pariet Filium et vocabitur nomen eius em[m]anuel".

Apart from the unusual detail of incorporating here -between the figure of God the Father and the Holy Spirit in the form of a white dove - the miniaturized image of a naked child (Jesus) descending towards Mary, to signify the conception / incarnation of the Son of God in the Virgin's womb, the monumentalized bed that Pere Serra includes in this painting is what is most relevant for our purposes. Filling almost half of the scene, and rising up to approach the ceiling, this huge bed, covered with green bedspread, occupies between the angel and the Virgin a place so prominent that it can be assumed endowed with some essential meaning. ${ }^{7}$

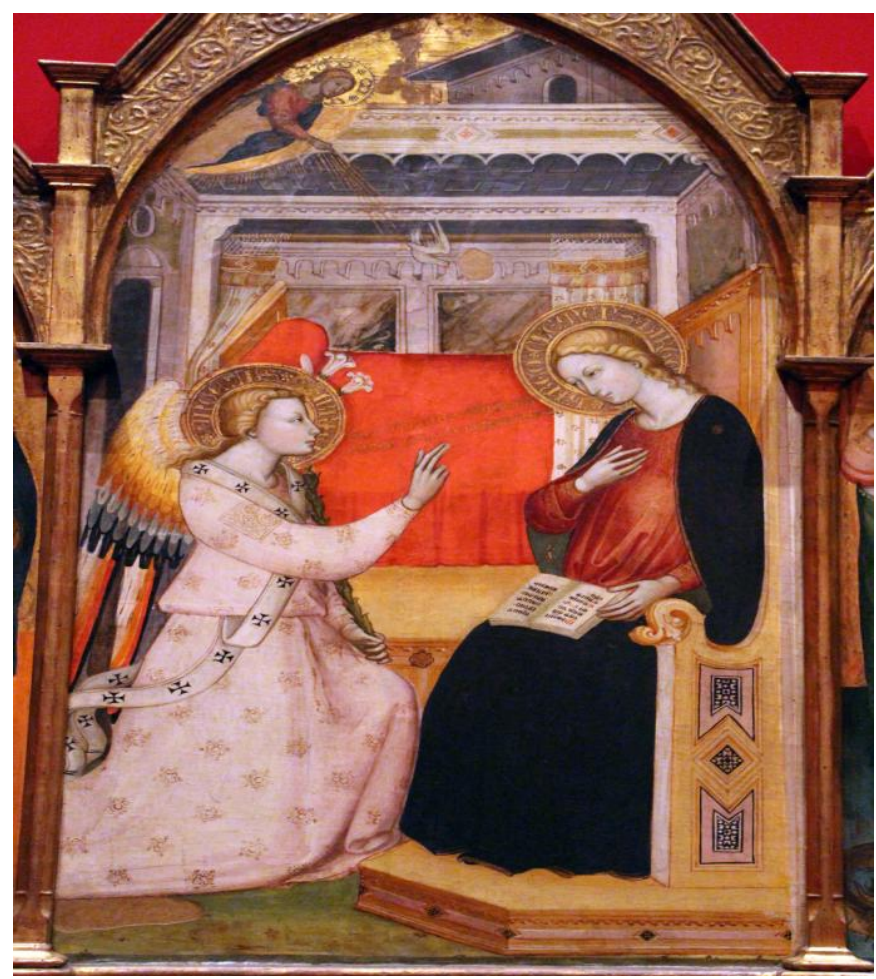

Plate4: Bicci di Lorenzo, L'Annunciazione, central panel of the Pala dell'Annunciazione con quattro santi, c. 1414, Pieve di Santa María Assunta, Stia. Foto: Wikimedia Commons: https://upload.wikimedia.org/wikipedia/ commons/8/87/Bicci_di_lorenzo\%2C_annunciazione_tra_i_ss._michele\%2C_giacomo_minore\%2C_margherita _e_giovanni_e.\%2C_1414_\%28stia\%2C_s.m._assunta\%29_02.JPG (Last access: 09/11/2019)

Bicci di Lorenzo proposes The Annunciation, central panel of the Altarpiece of the Annunciation with four saints, c. 1414, of the Pieve di Santa María Assunta in Stia (Plate 4), in a manner relatively similar to what the authors of the three newly analyzed paintings did. In fact, Bicci di Lorenzo also places here at the bottom and in the middle of the scene -excessively rearing it up, in an artificial perspective - a huge bed of red quilt, arranging it as well as the authentic physical and symbolic center around which the other elements of the scene, including its two protagonists, Gabriel and Mary, rotate. Clearly the iconographic programmer of this altarpiece wanted to give this bed such a central and prominent position, undoubtedly driven by the desire to invest it with a symbolic meaning of great doctrinal depth.

With a compositional structure relatively similar to that used by Bicci di Lorenzo in the painting analyzed above, Gentile da Fabriano places his Annunciation, c. 1423-1425, of the Pinacoteca Vaticana (Plate 5), in a small and narrow cubic enclosure: its rigid geometry, based on a plexus of static verticals and horizontals, is counterbalanced by means of the graceful curves of the Gothic

${ }^{7}$ In the current state of our researches, we do not know any historian who has been conceptually interpreting the bed of this Annunciation by Pere Serra. 
windows, the intertwining of the oriental carpet and the ornaments of the bank on which the Virgin sits. In front of her the angel begins to kneel, just entered through the door that communicates with the garden.

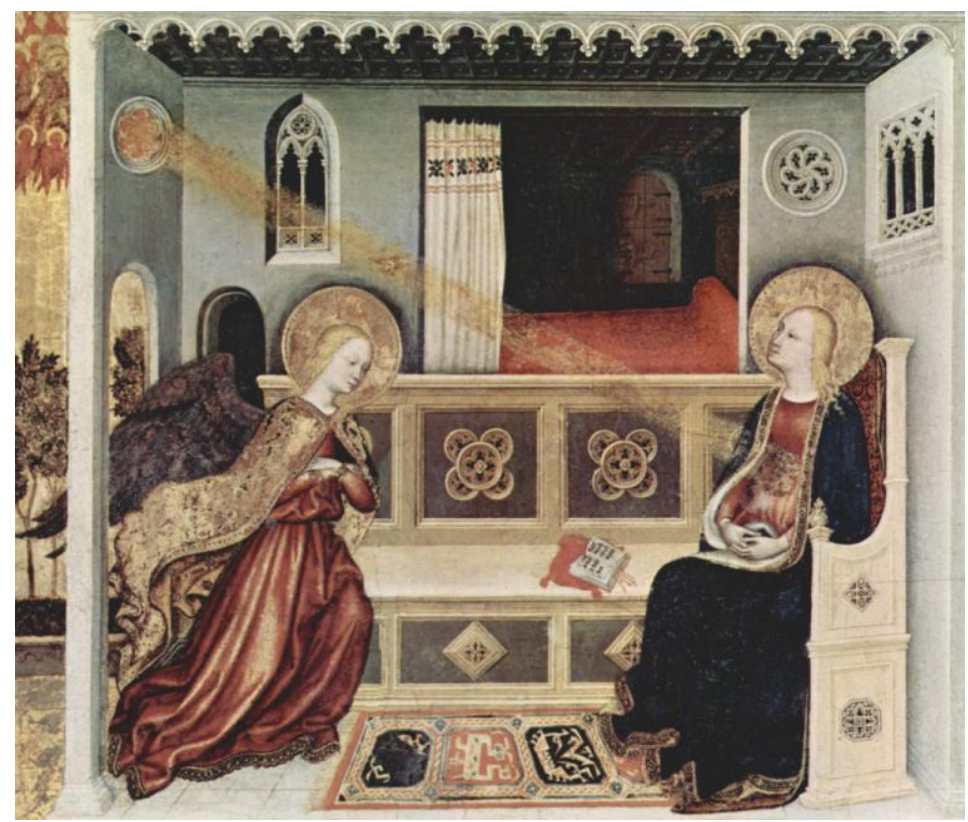

Plate5: Gentile da Fabriano, The Annunciation, c. 1423-1425. Pinacoteca Vaticana. Photo: Web Gallery of Art: https://www.wga.hu/support/viewer/z.html (Last access: 09/11/2019)

In the synthetic geometric scenery of this Annunciation in the Pinacoteca Vaticana, a sleeping room and a red bed are clearly visible -as a strong link between Gabriel and Mary-, whose intimacy partially protects a white curtain almost completely uncrossed. It is evident that, by highlighting these details, Gentile da Fabriano wants to give the sleeping room and the bed of Mary a very relevant meaning. Despite that, this meaning goes completely unnoticed to almost all the commentators of this panel, among whom we can mention Lasse Hodne ${ }^{8}$ and Vera-Simone Schulz, ${ }^{9}$ who say nothing about this bed.

In the splendid Annunciation (central panel of the today dismembered Triptych of the Annunciation, c. 1434-1435) preserved in the Musée du Louvre (Plate 6), Rogier van der Weyden poses the scene in a luxurious interior, with fine and rich furniture, full of objects and fabrics of showy elegance. In that refined bourgeois environment, the archangel, dressed as a priest with sumptuous cope ${ }^{10}$ of attractive trimmed ornament, approaches the Virgin cautiously and begins the kneeling gesture before her. Sitting in prayer with her open book, Mary expresses her surprise and fear at the unexpected visitor by raising her right hand and tilting her head to the side. Among the exquisite furniture that fill the room, a spotless red bed, whose privacy protects a slender baldachin and curtains of that same color, stands out above all, for its intense color, for its large dimensions and for its centrality in the middle of the scene.

Erwin Panofsky, in his extensive analysis of this Rogier van der Weyden's Annunciation in the Louvre ${ }^{11}$ offers certain unjustified or entirely wrong opinions and "interpretations." Let's examine these "interpretations" separately. First, despite recognizing that other contemporary or former

${ }^{8}$ Discussing this panel, Lasse Hodne (2015. "Light Symbolism in Gentile da Fabriano's Vatican Annunciation”, Eikón Imago, 6, 33-50), says nothing about the bed.

${ }^{9}$ Nor does Vera-Simone Schulz (2018. "Infiltrating Artifacts: The Impact of Islamic Art inFourteenth- and Fifteenth-Century Florence and Pisa", Konsthistorisk tidskrift/Journal of Art History, 87:4, 220) say anything about the bed of this painting of Gentile da Fabriano.

${ }^{10}$ On the form and function of the cope and other Christian liturgical vestments, see Ángel Pazos López, (2019). "La aparición de las vestiduras litúrgicas del cristianismo occidental en la iconografía tardoantigua y altomedieval". De Medio Aevo, 13, 241-248.

${ }^{11}$ Erwin Panofsky. (1966 [1953]). Early Nederlandish painting. Its origins and character. Cambridge, Mass.: Harvard University Press, p. 172, fig. 309b, and p. 173, fig. 310. 

Latin Patristics

painters, such as Masolino, Fra Angelico or Bicci di Lorenzo, also represent in their Annunciations a bed in a discreetly placed alcove, Panofsky states that Roger van der Weyden is, with this Annunciation of the Louvre, the first artist to bring to light the idea of thalamus Virginis. ${ }^{12}$ It would be necessary to point out to this prestigious iconographer that, in addition to the three artists mentioned by him, many other painters contemporary or previous to van der Weyden include in their Annunciations a bed: this is the case of, for example, Barna da Siena (or Lippo Memmi), Giovanni del Biondo, Pere Serra and Gentile da Fabriano in the paintings we have just analyzed, as well as Tommaso del Mazza (Master of St. Viridiana), ${ }^{13}$ Pietro di Miniato, ${ }^{14}$ the Master of the Annunciation of Brozzi (Giovanni dal Ponte?), ${ }^{15}$ and Gherardo Starnina. ${ }^{16}$

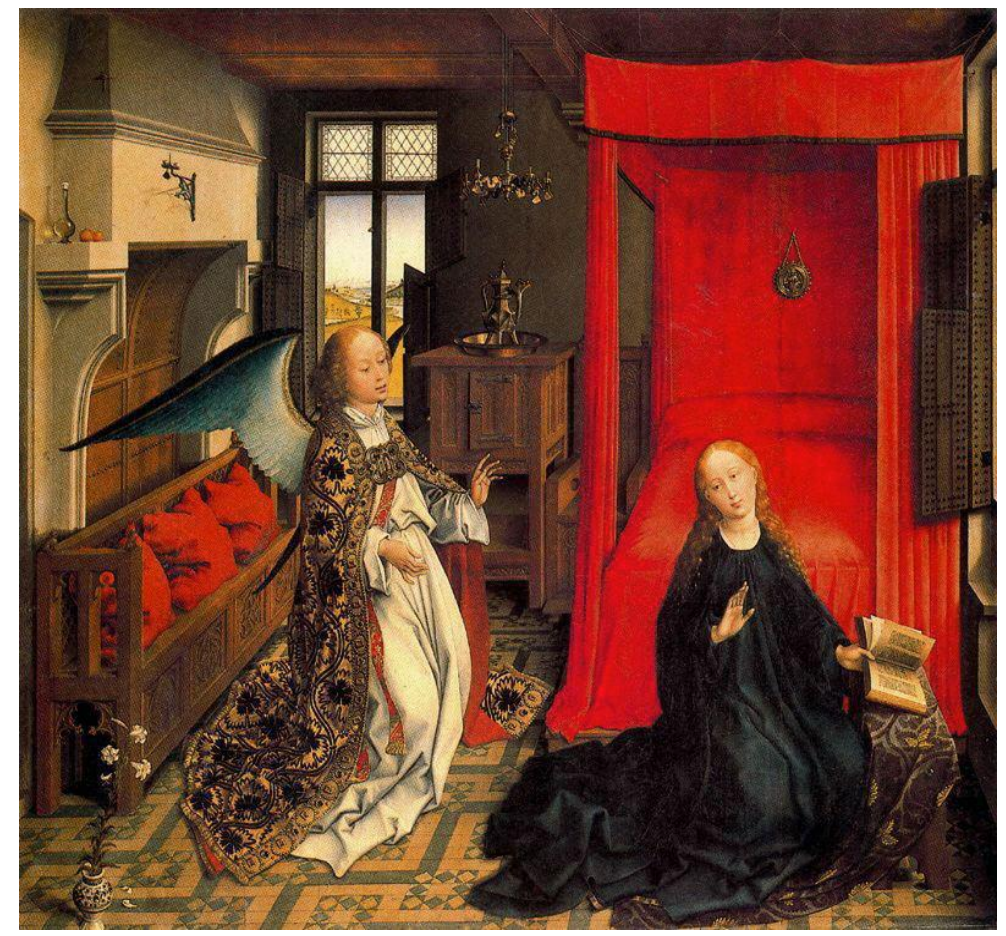

Plate6: Rogier van der Weyden, The Annunciation, central panel of the Tryptych of The Annunciation, c. 14341435. Musée du Louvre, Paris. Photo: Wikimedia Commons:

https://es.wikipedia.org/wiki/Rogier_van_der_Weyden\#/media/Archivo:Rogier_van_der_Weyden_-_ Annunciation_Triptych_-_WGA25590.jpg (Last access: 09/11/2019)

On the other hand, Panofsky insists on the idea that in this Annunciation of van der Weyden in the Louvre what appears to be at first sight a well-furnished living room of a bourgeois interior is actually "a bridal chamber", to the point that the scene of this Annunciation officially refers to the thalamus Virginis. ${ }^{17}$ Panofsky asserts, in effect, that the room represented here is "unequivocally a thalamus, a

\footnotetext{
12، And he [Rogier van der Weyden] was also the first to throw full light upon the idea of the thalamus Virginis. Where a bed appears in such contemporary or slightly earlier renderings as the Brenken altarpiece or the "Annunciations" by Masolino, Fra Angelico and Bicci di Lorenzo it is removed into an alcove in the rear or nearly hidden in an adjacent room, a modest footnote to the main text."(Panofsky 1966 [1953], vol. I, 254).

${ }^{13}$ Tommaso del Mazza (Master of St. Verdiana), The Annunciation, c. 1390. Paul Getty Museum, Los Angeles.

${ }^{14}$ Pietro di Miniato, Annunciazione e storie di Gesù, 1390-1399, affresco controfacciata di Santa Maria Novella, Florence.

${ }^{15}$ Maestro dell'Annunciazione di Brozzi (maybe Giovanni dal Ponte), Annunciazione tra santi Eustachio $e$ Antonio Abate, c. 1400-1420.

${ }^{16}$ Gerardo Starnina (attributed), La Anunciación, $15^{\text {th }}$ century, cathedral of Toledo, Capilla de San Blas.

${ }^{17}$ This is complemented by the text on Jan van Eyck's Arnolfini Portrait: "We begin to see that what looks like nothing but a well-appointed upper-middle-class interior is in reality a nuptial chamber, hallowed by sacramental associations and often sanctified by a special benedictio thalami; and that all the objects therein bear a symbolic significance. It is not by a chance that the scene takes place in a bedroom instead of a sitting room, for the matrimonial bed was so sacred that a married couple in bed could be visited and blesed by the Trinity, and even the scene of the Annunciation had come to be staged in what was officially referred to as the thalamus Virginis." (Panofsky 1966 [1953], Vol. I, 203).
} 
nuptial chamber", different from that represented by Jan van Eyck in The Arnolfini Portrait. ${ }^{18}$ To this sharp opinion two counter-augmentations could be contrasted: firstly, one does not see what is the essential difference between the room of The Arnolfini Portrait and that of the Virgin Mary in this Annunciation, since at first sight both have similar beds; secondly, and above all, the room where van der Weyden stages his Annunciation of the Louvre cannot be a bridal chamber (thalamus), because, even if it includes a large bed, it is evident that the objects (lamp, chandeliers, etc.) and the furniture (armchair, locker), the two large windows and, above all, the huge fireplace do not combine in any way with a bridal room, but with a lobby or living room.

Trying to justify his interpretations, Panofsky offers as primary source only this unfortunate statement: "For passages in which the Virgin Mary herself is called" thalamus pietatis "," thalamus humilitatis "," thalamus dei “, etc., see Patrologia Latina, Indices, vol. CCIX, col. 519).," It is very surprising that this respected master of iconography makes with this short sentence three serious mistakes: first, these expressions of the Patrologia Latina's index are not found in the volume CCIX (209), but in the CCXIX (219); moreover, in this volume the expression "thalamus dei" does not appear anywhere; thirdly, the correct expression inserted here is not "thalamus humilitatis", but the very significantly different "thalamus humanitatis Christi", ${ }^{20}$ which is just one of the interpretations that the Latin Fathers and theologians will give on the bed in the Annunciation, such as we will prove in the second part of this article.

Panofsky also states that the symbolic meaning of the bed in the Annunciation of van der Weyden would be manifested by the medallion suspended from the headboard which, according to him, represents the image of "the Lord" (God the Father). ${ }^{21}$ In fact, Panofsky does not specify in any way what symbolic meaning of the bed he refers to, nor does he justify what is the essential significant relationship between this alleged image of "the Lord"22 and the bed.

Several other art historians give on this van der Weyden's Annunciation in the Louvre various "interpretations" no less arbitrary. Thus, while Odile Delenda says that the painter accentuates the familiar aspect of the scene by representing the Virgin in her sleeping room, ${ }^{23}$ Albert Châtelet opts for two different interpretations, both similarly inconsistent. In a first book, in fact, Châtelet states that van der Weyden, by representing the Annunciation in Mary's sleeping room, placing the Virgin before the bed, emphasizes the idea of "her mystical union with Christ." ${ }^{24}$ On the contrary, in a second book published that same year (1999) Châtelet asserts that the artist, when representing this

\footnotetext{
18“'In Roger's Louvre panel the Annunciation chamber itself is conspicuously and unequivocaly characterized as a thalamus, a nuptial room not unlike the interior in the Arnolfini portrait". (Panofsky 1966 [1953], vol. I, 254).

${ }^{19}$ Panofsky 1966 [1953], vol. I, p. 203, n. 35.

${ }^{20}$ The correct formulation of that Vol. 219, col. 519 is: "Thalamus humanitatis Christi, S. Cyprianus, De Nativit, Domin., V; S. Ambrosius, Comm. Confess., XVI.

Thalamus pietatis. S. Bernardus, Super Salve, CLXXXIV.

Thalamus sanctitatis. S. Odilo. De Assumpt., CXXXII. S. Rupertus, de divin. ofic,., CLXIX.” (PL 219, 519).

${ }^{21}$ “'the symbolic significance of the bed is clearly manifested by the fact that the chased medallion suspended from its headboard bears the image of the Lord."(Panofsky 1966 [1953], Vol. I, 254).

${ }^{22}$ Antje-Fee Köllermann contradicts this interpretation of Panofsky, indicating: "Panoksy $(1953,254)$ believed that he recognized God the Father as the true husband of the Virgin Mary in the medallion, and he was convinced that this confirmed his theory of Mary's bridal chamber. The figure depicted, however, is that of Christ Pantocrator, as Lorenz /Comblen-Sonkes (2001, p. 249) have quite rightly pointed out." (Antje-Fee Köllermann, 2009, 306, n. 3).

${ }^{23}$ Glossing this Annunciation of the Louvre, Odile Delenda (1987. Rogier van der Weyden (Roger de Le Pasture). Paris: Cerf, Tricorne, 33-36), only says in reference to our subject: "Rogier accentue le côté familier de la scène en montrant la Vierge dans sa chambre à coucher". (Delenda 1987, 33). We could object to Delenda that "the familiar aspect" could have manifested more appropriately in the "public" spaces of the house, such as the living room, the kitchen or the laundry room, instead of in the "private" and intimate space of the bridal chamber..

${ }^{24}$ Albert Châtelet, (1999a. Rogier van der Weyden (Rogier de le Pasture). Paris: Gallimard), commentating this Annunciation of the Louvre, states: "Comme Robert Campin (Triptyque de Mérode, New York, The Cloisters), Rogier van der Weyden a représenté l'Annonce à Marie dans un intérieur bourgeois. Il a préféré, toutefois, situer la scène dans la chambre. En plaçant la Vierge devant le lit, il met ainsi plutôt l'accent sur l'idée de son union mystique avec le Christ." (Châtelet 1999a, 43).
} 
Annunciation in the thalamus of the Virgin, refers to "the mystical union of the Virgin and the Holy Spirit", adducing for it, as an authority argument, a brief quote from the Pseudo-Bonaventure. ${ }^{25}$

Faced with such equivocal opinions of Châtelet, we could oppose three objections: it is surprising, above all, that in two books of the same year Châtelet affirms first that the thalamus of the Virgin means her mystical union with Christ, while, in his second book of this same year, affirms that it means the mystical union with the Holy Spirit; secondly, it is not clear what this "mystical marriage" consists of (be it with Christ, be it with the Holy Spirit); finally, why rely on the doctrinal "authority" of Pseudo-Bonaventure (which, besides being a pseudo, has no major influence on the later thinkers), while many prestigious Fathers and theologians of the Latin and Greek-Eastern Churches insist on and again in offering coincidental dogmatic interpretations on the bed -referred to the human incarnation of God the Son in the womb of Mary-, as we will show in the second part of the current article?

The "interpretations" of Dirk De Vos on the bed in this Annunciation of van der Weyden are also unacceptable. De Vos begins by repeating some views of Panofsky, such as that of van der Weyden is partially inspired by The Arnolfini Portrait, and that it is probably the first representation of the Annunciation in the Virgin thalamus. Then De Vos states that this great bed is certainly related to marriage, but to "a marriage in the mystical sense, the one that unites Mary, as a Church, and her Husband Christ." ${ }^{26}$ Without needing to repeat the observations that we already addressed to Panofsky, on which Dirk De Vos relies, we would object to this last author two important shortcomings: first of all, he does not justify from what primary doctrinal sources he takes the idea that this bed of the Louvre painting means the mystical union of Mary with Christ; secondly, he does not justify either from which Church Fathers or Christian theologians he extracts the ideas that the Virgin is the Church, and that the Church is the Bride of Christ.

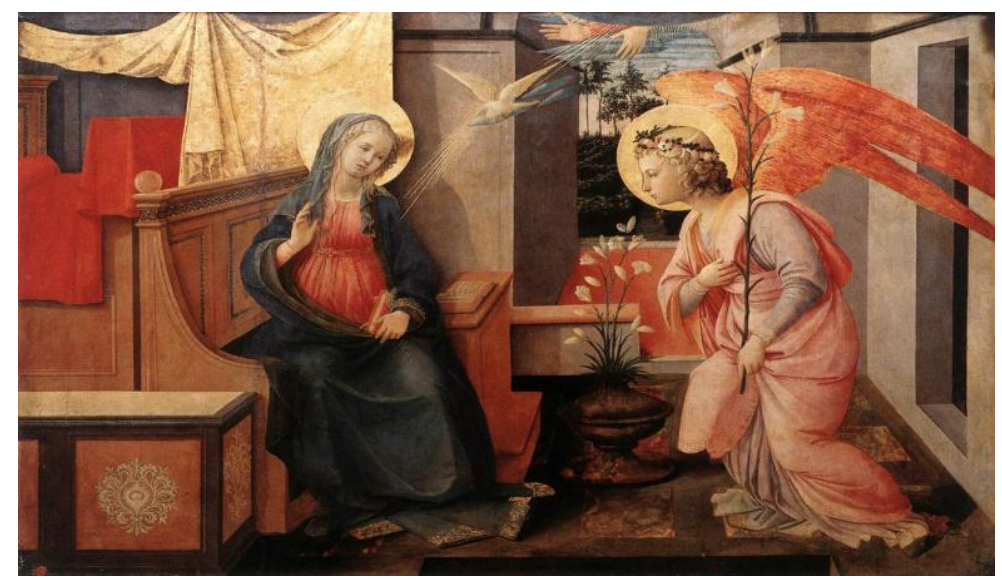

Plate7: Fra Filippo Lippi, The Annunciation, 1445-1450. Galleria Doria-Pamphilj, Roma. Photo Wikimedia Commons: https://commons.wikimedia.org/wiki/File:Annunciation,_Rome_-_Fra_Lippi.jpg (Last access: 17/11/2019)

\footnotetext{
${ }^{25}$ Albert Châtelet, (1999b. Rogier van der Weyden. Problèmes de la vie et de l'ouvre. Strasbourg: Presses Universitaires de Strasbourg), in his commentary on this Annunciation by van der Weyden in the Louvre (pp. 97-99), states: "La composition est directement inspirée par le Triptyque de Mérode, mais avec des modifications importantes et significatives. D'une scène situé dans le logis de la Vierge -cubiculum —on passe à une représentation dans la chambre -thalamus - qui implique une allusion à l'union mystique de la Vierge et du Saint Esprit: elle est reconnnue et prise par le Père pour fille [ce qui rappelle le médaillon de cuivre représentant Dieu le Père suspendu à la courtine du lit], par le Fils pour mère, par l'Esprit Saint, pour épouse (Pseudo-Bonaventure)." (Châtelet 1999b, 97).

${ }^{26}$ In his extensive commentary on Rogier van der Weyden's Annunciation in the Louvre, Dirk De Vos (1999. Rogier van der Weyden. L'ouvre complet. Paris: Hazan, p. 98, fig. 123, and p. 195-199), after saying that this painting is partially inspired by Jan van Eyck's Arnolfini Portrait -"Telle est la source du lit à baldaquin rouge" (De Vos 1999, 199) —, asserts: "Comme nous l'avons déjà fait observer, il s'agit peut-être de la plus ancienne représentation de l'Annonciation dans le "thalamus", qui est ici devenu une chambre à coucher du $\mathrm{XVe}$ siècle. [...] Le grand lit, qui apparait ici pour la première fois dans une Annonciation, se rapporte certes au mariage, mais mariage au sens mystique, celui qui unit Marie, en tant qu'Église, et son Époux le Christ." (De Vos 1999, 196).
} 

Latin Patristics

Fra Filippo Lippi, in The Annunciation, 1445-1450, of the Galleria Doria-Pamphilj in Rome (Plate 7), includes some unusual details, such as reversing the position of the two protagonists, placing the angel on the right side and the Virgin on the left, or that of duplicating the stem of lilies, one in Gabriel's hand, and the second in a vase on the floor. However, what is important to highlight here is the large red bed, protected by an open light curtain, which stands out in the upper left part of the painting. It is clear that Lippi wants to suggest the symbolic importance of this bulky bed, which is surprisingly not even mentioned by many commentators of this picture, as is the case with Giuseppe Marchini, ${ }^{27}$ Jeffrey Ruda, ${ }^{28}$ Megan Holmes, ${ }^{29}$ and Gloria Glossi and Eliana Princi. ${ }^{30}$

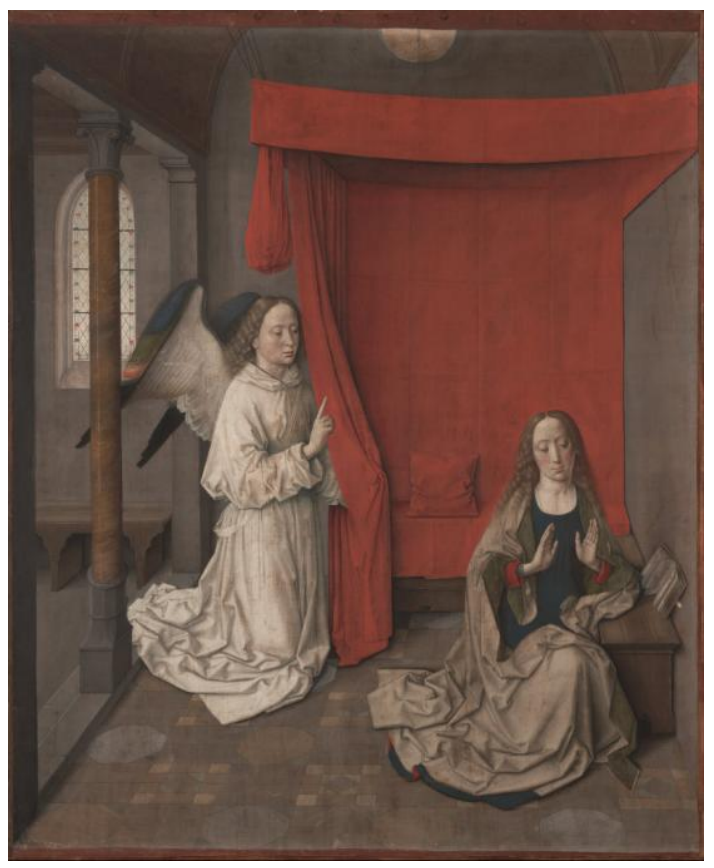

Plate8: Dirk Bouts,The Annunciation, c. 1450-1455. Getty Center, Los Angeles. Photo: Getty Center, Los Angeles: http://www.getty.edu/art/collection/objects/754/dieric-bouts-the-annunciation-netherlandish-about1450-1455/ (Last access: 08/11/2019)

In his Annunciation, c. 1450-1455, from the Getty Museum in Los Angeles (Plate 8), Dirk Bouts represents the angel Gabriel with the gesture of pointing his right index upwards, as an eloquent way to signify the announcement that communicates to Mary: the Holy Spirit would come over her and the power of the Most High would cover her with his shadow, to make possible the incarnation of the Son of God in her virginal womb. Sitting humbly on the floor and lowering her eyes, Mary expresses her surprise and unconditional acceptance of the divine design through the gesture of raising her hands, similar to how a priest does when officiating Mass.

In this scene the large red bed that, although unexpectedly cut in depth (at first glance it seems very narrow), is fully defined by the canopy and the red curtains that protect its privacy, is the most interesting element for us. A suggestive detail, because of the unusual, is the fact that the angel himself partly lifts the side curtain that surrounds the bed, almost as if to reinforce the idea that his heavenly announcement -the human incarnation of God the Son - is symbolized through this clear and spotless bed, as we will show in the second part of this article.

Also Petrus Christus, in The Annunciation of the upper panel of the left wing of the Triptych of the Annunciation, the Nativity and the Last Judgment, 1452, in the Gemäldegalerie of Berlin (Plate 9),

\footnotetext{
${ }^{27}$ Glossing this Annunciation by Lippi, Giuseppe Marchini (1979. Filippo Lippi, Milano: Electa, p. 204, fig. 39), does not mention the bed

${ }^{28}$ In his comment on that painting by Lippi, Jeffrey Ruda (1993. Fra Filippo Lippi. Life and Work with a Complete Catalogue. New York: Harry N. Abrams, p. 163-165, pl. 91-92, and p. 428, fig, 265), says nothing about the bed..

${ }^{29}$ Megan Holmes. (1999). Fra Filippo Lippi. The Carmelite painter. New Haven: Yale University Press.

${ }^{30}$ In their comment on this Annunciation, Gloria Glossi \& Eliana Pinci (2011 [1989]. Filippo e Filippino Lippi. Firenze: Scala, 33) do not mention the bed.
} 

Latin Patristics

emphasizes the doctrinal meanings that we will explain in the second part of the current paper. The painter achieves this purpose by artificially placing a huge green bed, with its canopy and curtains of the same color, in the middle of a living room (not a bridal chamber), furnished with great luxury and widely open to the outside by the windows and the entrance door to the house from the garden. Filling almost half of the compositional space, and located just behind the Virgin -as identifying itself with her- that huge bed thus clearly reveals the relevance of its symbolic meaning.

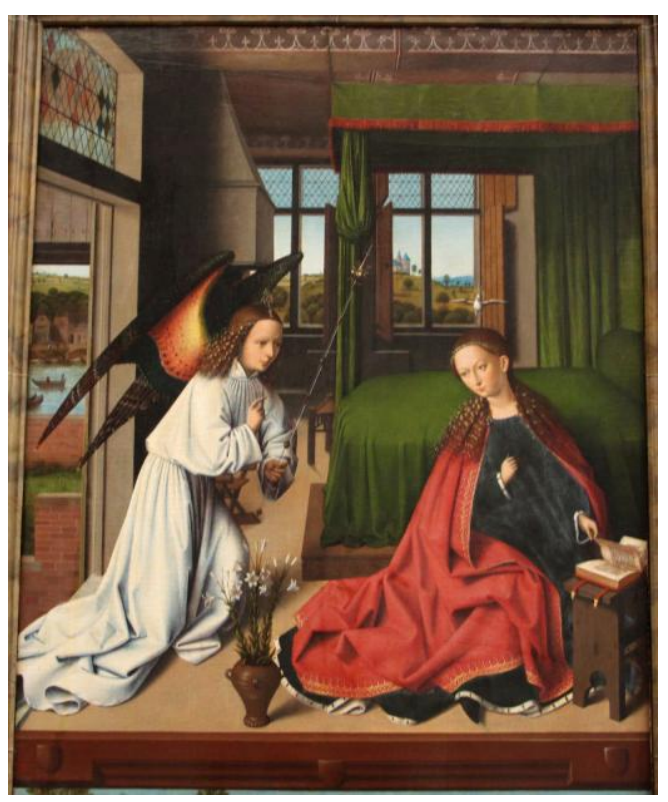

Plate9: Petrus Christus, The Annunciation, upper panel of the left wing of the Triptych of the Annunciation, the Nativity and the Last Judgment, 1452. Gemäldegalerie, Berlin. Photo: Wikimedia Commons:

https://commons.wikimedia.org/wiki/Category:Last_Judgement,_Annonciation_and_Nativity_of_Christ_by_Pet rus_Christus\#/media/File:Petrus_christus,_annunciazione,_nativit\%C3\%A0,_e_giudizio_universale,_1452,_02.J PG (Last access: 09/11/2019)

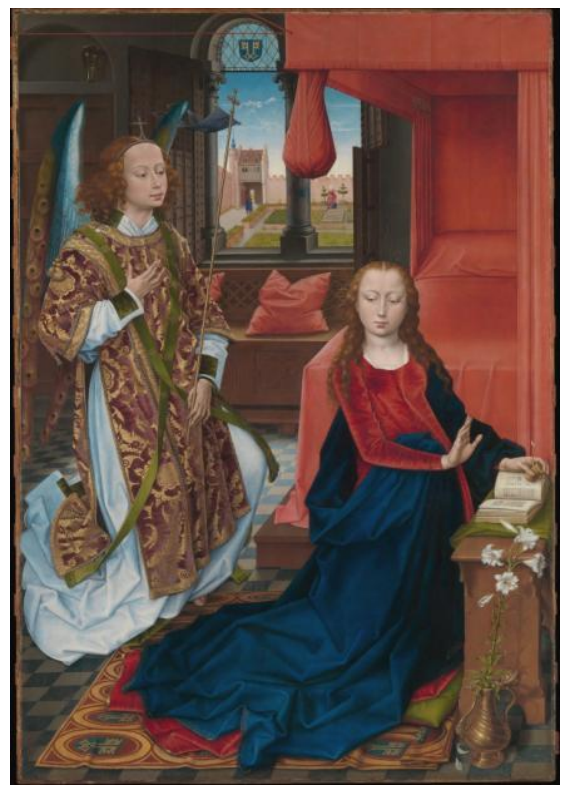

Plate10: Hans Memling (or Workshop of Rogier van der Weyden), The Clugny Annunciation, c. 1465-1475, Metropolitan Museum, New York. Photo Wikimedia Commons:

https://upload.wikimedia.org/wikipedia/commons/8/86/Clugny_Annunciation.jpg

Also Hans Memling (or a member of the workshop of Rogier van der Weyden) also interprets the event of The Clugny Annunciation, c. 1465-1475, of the Metropolitan Museum in New York (Plate 10), analogously to what Petrus Christus did in the preceding panel. The author of this painting in the New York museum places the Annunciation in a colorful hall (not a bridal chamber) generously open 
to the garden through the wide bigeminated window. Within the framework of that splendid bourgeois interior the angel, dressed in rich ecclesiastical clothing, presents the heavenly message to the Virgin, She, kneeling in the recliner before the open book, interrupts her prayer with a gesture of surprise and demure, raising her right hand in sign of acceptance before the design of the Most High. In perfect continuation (analogy of identification) with the figure of Mary, an sumptuous and spotless red bed illustrates the dogmatic meanings that we will explain later from the perspective of the Fathers and theologians of the Latin Church.

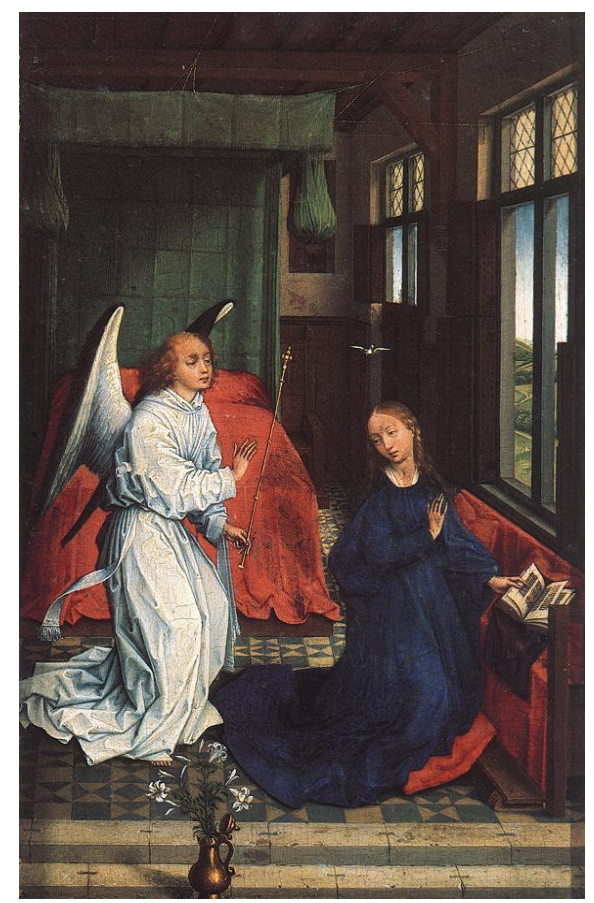

Plate11: Workshop of Rogier van der Weyden, The Annunciation, c. 1450, Koninklijk Museum voor Schone Kunsten, Antwerp Photo Wikimedia Commons:

https://commons.wikimedia.org/wiki/File:Rogier_van_der_Weyden_-_Annunciation_-_WGA25596.jpg\#/ media/File:Rogier_van_der_Weyden_-_Annunciation_-_WGA25596.jpg (Last acces: 17/11/2019)

The artist who, following the design of Rogier van der Weyden, painted The Annunciation, c. 1450, of the Royal Museum of Fine Arts in Antwerpen (Plate 11), repeats not few items established in this iconographic theme by his master and other contemporary Flemish painters. That is why he staged the dialogue between the two interlocutors of the Marian event within an exquisite room. Its luxurious furniture, as well as the circumstances of having the access door directly from the outside, and the wide windows open to the landscape, typify this room as the living room or the lobby of Mary's house, and not as her bridal chamber. We do not share, therefore, the interpretation of Stephan Kemperdick, who, in commenting on this picture of Antwerp, says that, according to Vita Jesu Christi, by Ludolf von Sachsen, a very popular work in the Middle Ages, the Annunciation took place in the thalamus, Mary's sleeping room. ${ }^{31}$ We could, in fact, ask why Kemperdink rely on the rather late Ludolf von Sachsen (c. 1300-1377 / 1378), instead of relying on many other Fathers and theologians who were much earlier and much more influential than this lesser known German Carthusian of the 14th century.

In any case, the van der Weyden's follower who embodied this painting of Antwerp, in staging the dialogue between the angel and Mary in this magnificent hall, highlights with particular emphasis a huge red bed, unusually protected here by a green canopy and curtains of this same color. The unexpected inclusion of such a bed in the center of the living room allows us to undoubtedly guess the relevance that the intellectual author of this painting wants to give to the bed as a symbol of deep doctrinal meanings, as we will see later.

\footnotetext{
${ }^{31}$ Kemperdick, S. \& Sander, J. (ed.). (2009). The Master of Flémalle and Rogier van der Weyden (exhib. cat.), Städel Museum, Frankfurt am Main, and the Gemäldegalerie, Staatliche Museen, Berlin, Ostfildern, Hatje Cantz, 376.
} 


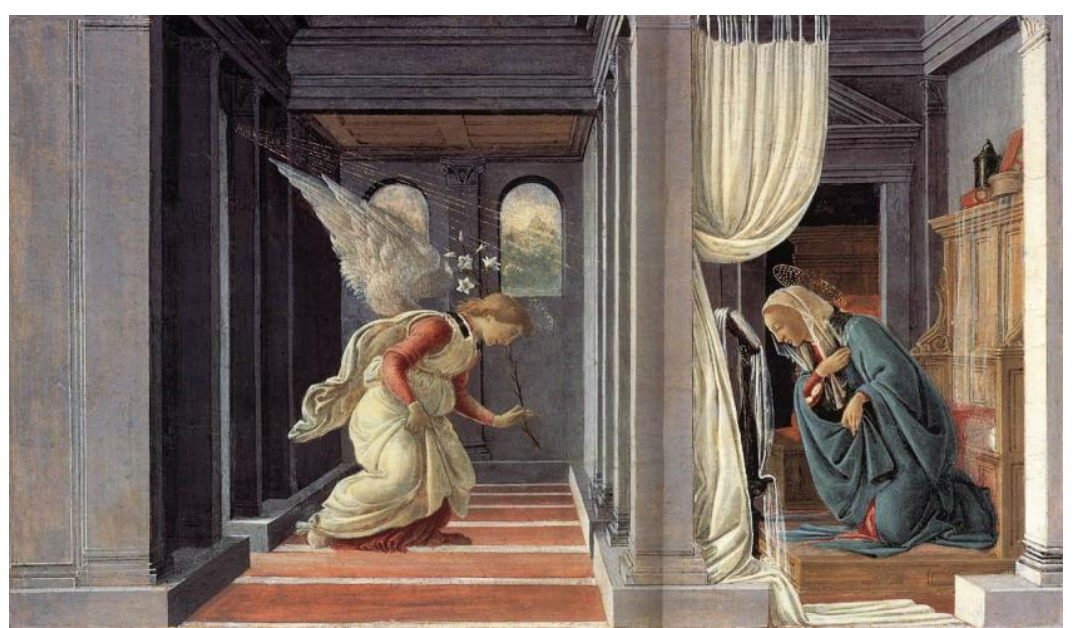

Plate12: Sandro Botticelli, The Annunciation, c. 1485. Metropolitan Museum, New York. Photo The Metropolitan Museum, New York: https://www.metmuseum.org/es/art/collection/search/459016

Sandro Botticelli, in his Annunciation, c. 1485, in the Metropolitan Museum of New York (Plate 12), structures the scene with extreme simplicity, reducing the scenery to mere construction elements: pilasters, walls, windows, pavement, ceiling, etc., completely dominate the scene, leaving only a slight respite to the furniture in the right room, where the Virgin is staying. At the bottom of that room you can see the sleeping chamber of Mary, in which a red bed is distinguished in compositional continuity (symbolic identification) with her figure.

Now, almost all the commentators of this Botticelli panel silence the presence of this important bed. An exception is Ronald Lightbown, who, after mentioning it (whose symbolic meaning completely escapes him), incurs in the banality (pure formalism) of highlighting the compositional contrast between the white curtain's curve of the first term and the numerous vertical and horizontal rectilines that dominate the whole. ${ }^{32}$ From what we will show in the second part of the paper, in the light of the exegetical tradition of the Latin Fathers, Botticelli wanted to include a bed in this Annunciation, probably because he is aware of the doctrinal meanings contained in this symbolic piece of furniture.

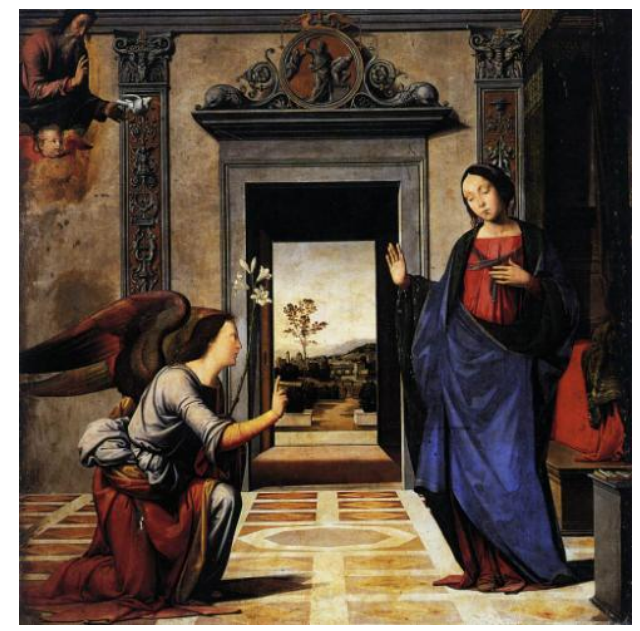

Plate13: Fra Bartolomeo, The Annunciation, 1497. Cathedral of Volterra. Photo Wikimedia Commons: https:// commons.wikimedia.org/wiki/File:Fra_bartolomeo_01_Annunciation.jpg (Last access: 09/11/2019)

In his Annunciation, 1497, in the Cathedral of Volterrra (Plate 13), Fra Bartolomeo places the scene of

\footnotetext{
${ }^{32}$ Commenting this Annunciation by Botticelli in the Metropolitan Museum of New York, Ronald Lightbown (1989. Botticelli. Life and work, London, Thames and Hudson, p. 214-215, pl. 84), points out: "The still life is another of Botticelli's translations of a Flemish motif; so too is the opening of the background into a deeper space behind, on the left by windows looking onto a landscape, on the right by the dark bedroom entered through a pedimented doorway and containing a bed with a bermilion coverlet and a stool. The eye is attracted to this complex compartamentalization of space by the white curtain drawn across the front of the Virgin's room, which also serves to modify the rigid lines of the architecture." (Lightbown 1989, 215).
} 
this Marian event in a resplendent Renaissance palace: this is illustrated by its elegant pavement of polychrome marbles, its fine pilasters decorated a candelieri, and its attractive door open to the garden, whose gable represents in relief the Sacrifice of Isaac. In this magnificent setting, the angel kneels respectfully before Mary. With the gesture of bowing her head, lowering her eyes and raising her right hand, she humbly expresses her unrestricted obedience to the divine design, after proclaiming herself ancilla Domini. In the luxurious palatial atmosphere represented here, Fra Bartolomeo also includes a red bed to the right of the composition. Although discreetly almost hidden by the darkness of the room where it is located, that bed acquires here, as in the other Annunciations discussed above, a great significant value, as we will show soon in the light of numerous testimonies of Latin Fathers and theologians.

\section{From A DISTURBING PROBLEM TO A SATISFACTORY SOLUTION}

\subsection{Finding a Problem, Venturing Some Hypotheses}

As seen in the select set of pictorial works that we have analyzed here -and in many others not included in this small selection-, in the Italian, Flemish, Spanish, German and French images of the Annunciation of the 14th and 15th centuries you can very frequently find a bed. In addition, this bed is almost always distinguished by its large dimensions, its neatness and beauty (always spotless and tidy), its prominent position (often in the center of the scene), and its eloquent function as a link that binds together the angel and Mary.

Now, this reiterative inclusion and this manifest prominence of the bed that so many different artists from such diverse countries, such as Italy, Flanders, Spain, Germany or France, include in some Annunciations of the 14th and 15th centuries carry a disturbing question: Is that bed an accidental chance, a simple fancy of the artist, a mere decorative or compositional detail with no significant value? Or is it, on the contrary, a symbol that contains some doctrinal meaning relatively important?

In this way, the following four hypotheses can be formulated:

- The bed that so many different artists from such different countries include in some images of the Annunciation of the 14th and 15th centuries, highlighting it almost always with large size and in prominent position, would not be a pure chance, nor a mere whim of the artist, not an insignificant decorative or compositional detail.

- Being this bed an element which appears in the episode of the Annunciation to Mary, and only in this Marian episode, it is reasonable to conjecture that it has some kind of necessary relationship with both the incarnation of God the Son in the virginal womb of Mary, as with the complementary Mary's virginal divine maternity, which are the two essential dogmatic nuclei in which the Annunciation of the angel to Mary is condensed.

- Therefore, it seems logical to assume that this bed included by so many Italian, Flemish, Spanish, German or French artists in many Annunciations of the 14th and 15th centuries is a symbol full of deep doctrinal meanings, which we must try to discover and justify on documentary bases.

- It seems reasonable to predict that the solution to the iconographic problems posed by this bed in the aforementioned images may most likely be found in the primary sources of Christian doctrine, especially in the writings of the Church Fathers and medieval theologians who have lectured on the thalamus concept.

\subsection{Discovering the Solution: Interpretations of Latin Fathers and Theologians on Thalamus}

As we had assumed, a long and rigorous investigation into the patristic and theological primary sources of the Eastern and Western Churches did not take long to reveal the answer we were looking for to this amazing symbolic element (thalamus). It suits to point out that in Latin the concept thalamus means both "nuptial bed" (or simply "bed") as "room or nuptial chamber". And it is to this double meaning that almost all the consulted Christian writers refer to.

What we offer below is just a selection of exegetical texts of Latin Fathers and theologians, which complement as many exegeses of Eastern Fathers and theologians, which we study in another article.

Already in the second half of the 4th century St. Ambrose (330-397), bishop of Milan and influential 
Father of the Church, subtly alludes to the supernatural conception / incarnation of Jesus in the virginal womb of Mary, and to his prodigious birth without destroying the virginity of his Mother, when he proclaims in his Hymn IV:

[Christ] Coming from his thalamus [bridal chamber]

Royal hall of modesty,

Giant of two twin natures [the divine and the human],

To run the road fast ${ }^{33}$

A generation later St. Maximus ( $\uparrow$ c. 420 ), the first bishop of Turin, retakes this same symbol of the thalamus in a different way in his Sermon 42 . He begins by saying that God planned to associate Mary as the thalamus of Christ, in which he became incarnate as a man from her own fleshly substance, according to the Psalm 18 "He himself comes from his thalamus as a husband." ${ }^{34}$ Then, after remembering the antecedent that King David sang and danced with joy before the Hebrew ark of covenant, St. Maximus asserts that Mary is a holy ark better than the old ark of the covenant, because, if it contained the tables of the Old Testament, Mary gestated the heir of that same Testament (Jesus); and, if that contained the old law, Mary contained the Gospel; and, if the ark of the covenant contained the voice of God (revealed to Moses), Mary contained the true Word of God; and, if this one shone inside and outside with the glow of earthly gold, Mary shines inside and outside with the glow of heavenly virginity. ${ }^{35}$

Three or four decades later St. Peter Chrysologus (c. 380-451), archbishop of Ravenna and Father of the Church, in a sermon on the Incarnation of the Son of God begins wondering rhetorically who, being unworthy, could approach the palace divine's doors. In response to this question, he points out that no one is admitted to approach the thalamus of the husband but only one who is quite close and intimate to him, who has a good conscience and laudable reputation. And then concludes by stating that, instead, within the thalamus itself (of God the Son) only the Virgin fits, only an immaculate virginity is received (that is, Mary). ${ }^{36}$

A century and a half later the exquisite hymnographer St. Venantius Fortunatus (c. 530-c. 607/609), bishop of Poitiers, repeatedly expresses this doctrinal symbolism of the thalamus in several poems. Thus, in one of them he points out:

The temples of the Creator are the chaste members of the maiden,

And God himself inhabits this bridal chamber.

How much she can please as a wife for her virginity,

The same mother of God pleases precisely as a virgin. ${ }^{37}$

\footnotetext{
33،"Procedens de thalamo suo

Pudoris aula regia,

Geminae Gigas substantiae,

Alacris ut currat viam." (Ambrosius Mediolanensis, Hymnus IV. PL 16, 1.411).

34"'Praevidebat enim in spiritu Mariam de germine suo Christi thalamo sociandam. Unde ait: Et ipse tamquam sponsus procedet de thalamo suo (Psal. XVIII)." (Maximus Taurinensis, Sermo 42, 5. PL 57, 738-739).

35، Arcam autem quid nisi sanctam Mariam dixerimus? Siquidem arca intrinsecus portabat testamenti tabulas, Maria autem ipsius testamenti gestabat haeredem. Illa intra semet legem, haec Evangelium retinebat. Illa Dei vocem habebat, haec Verbum verum; tamen arca intus forisque auri nitore radiabat, sed et S. Maria intus forisque virginitatis splendore fulgebat. Illa terreno ornabatur auro, ista coelesti." (Ibid.).

${ }^{36}$ "Quis ad ipsas palatii fores vilis, quis propinquat indignus? Certe ad thalamun sponsi nisi satis proximus, nisi satis intimus, nisi bonae conscientiae, nisi laudabilis famae, nisi probabilis vitae nullus admittitur. Intra thalamum vero ipsum virginem capit solam; suscipitur sola virginitas inlibata." (Petrus Chrysologus, Sermo CXLI. De Incarnatione Domini. PL 52, 577-588).

37، Templa Creatoris sunt membra pudica puellae, et habitat proprius tale cubile Deus

Quantum sponsa potest de virginitate placere,

ipsa Dei genitrix nonnisi virgo placet." (Venantius Fortunatus, Miscellanea. Liber VIII. Caput VI. In nomine Domini nostri Jesu Christi et Domnae Mariae Matris eius de virginitate. PL 88, 268-269).
} 
And, in another hymn in honor of Mary, Venantius Fortunatus insists:

Christ is who comes from above as a husband from his thalamus,

And exults as a giant walking the road,

Oh, thalamus of the womb [Mary], a new union made of salvation,

With whom [one who is] God, and also [is] flesh, married as a new honor!

With which God embraced the flesh, the flesh united together.

God remains, and becomes man, Christ [with] both natures [divine and human]. ${ }^{38}$

Almost two centuries later St. Isidore (c. 556-636), archbishop of Seville, in an apologetic book against the Jews, argues that Jesus Christ was born admirably as a husband who comes from his nuptial room, that is, from the womb of the Virgin Mary, after whose birth Mary did not have intercourse with anyone, nor fathered any other child in her womb. ${ }^{39}$

About three decades later St. Ildefonsus (607-667), archbishop of Toledo, in a treatise on the perpetual virginity of Mary, argues that she is the thalamus of God, because the incarnate Son of God came from her womb, as the husband mentioned in Psalm 18, preserving her virginity perpetually. ${ }^{40}$

Four centuries later, the Benedictine reformer and Cardinal St. Peter Damian (1007-1072), in a letter about the Annunciation retakes with remarkable lyricism the same metaphorical figure. In this text the holy monk, after indicating that the Almighty Son of God, eternal in his divine majesty, covered himself with the veil of the weak human flesh, asserts that, by joining the Word of God the Father to human nature, the heavenly Husband associated himself with his holy Church in the thalamus of Mary's virginal womb, for the sake of which (the Church) He whose infinite immensity heaven cannot contain did not despise the anguish of the mother's womb. ${ }^{41}$

And in a sermon on the birth of the Virgin Mary, Peter Damian states that, just as it was impossible for the redemption of Mankind to take place unless the Son of God was born of a Virgin, so the existence of this Virgin was necessary from whom the Word of God became flesh. Therefore, it was convenient to build a house in which the King of heaven, when descending to earth, deigned to have as lodging. ${ }^{42}$ For the same reason it was first necessary to erect a bridal chamber that would receive the Husband coming to marry his Holy Church, that same Husband (Christ) whose epitalam sang exultant David, saying in Psalm 18: "The Lord coming from his thalamus like a husband.",33

\footnotetext{
38،Qui tanquam sponsus thalamo procedit ab alto,

Exsultatque gigas Christus, eundo viam,

O uteri thalamus, nova junctio facta salutis,

Qua Deus, atque caro nupsit honore novo!

Quo Deus amplexus carnem est, caro juncta cohaesit,

Stat Deus, atque homo fit, Christus utrumque genus." (Venantius Fortunatus, Miscellanea. Liber VIII. Caput VII. In laudem sanctae Mariae Virginis et matris Domini. PL 88, 277).

39"Dominus enim noster Jesus Christus mirabiliter et potentialiter natus, tanquam sponsus processit de thalamo suo (Ps. XVIII,6, id est. ex Virginis utero, post cujus ortum nullum cum Maria convenisse, nullum ex ejus utero genitum exstitisse profitemur." (Isidorus Hispalensis, De fide Catholica contra Judaeos. Liber Primus, X, 10. PL 83, 470).

40، Haec virgo in psalmo thalamus Dei est, quia de utero ejus iste incarnatus Deus processit velut sponsus, in ea relicto perennis virginitatis decore mansuro (Psal. XVIII).» (Hildefonsus Toletanus, Liber de virginitate perpetua S. Mariae adversus tres infideles, III. PL 96, 66-67).

41،'Infirmae se carnis obtexit velamine, qui erat omnipotens in perennis essentiae majestate; dumque se humanae naturae Verbum Patris univit, in virginalis alvi thalamo coelestis Sponsus sanctam sibimet Ecclesiam foederavit, pro cujus amore angustias materni non dedignatus est uteri, qui infinita latitudine non capitur coeli." (Petrus Damianus, Carmina et preces. XVI. In eadem annuntiatione beatissimae virginis Mariae. Ad missam, Praefatio. PL 145, 934).

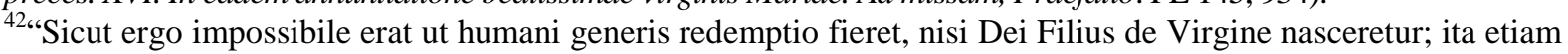
necessarium fuerat ut Virgo, ex qua Verbum caro fieret, nasceretur. Oportebat quippe prius aedificari domum, in quam descendens coelestis Rex habere dignaretur hospitium”. (Petrus Damianus, Sermo XLV. II. In Nativitate Beatissimae Virginis Mariae (VIII Sept.). PL 144, 741-742).

${ }^{43}$ "Necesse erat prius erigi thalamum, qui venientem ad nuptias sanctae Ecclesiae susciperet Sponsum, cui David, exsultans in spiritu, epithalamium canit, dicens: 'Tanquam sponsus Dominus procedens de thalamo suo (Psal. XVIII)'.” (Ibid.).
} 
Some decades later St. Anselm, (1033-1109), Benedictine prior and archbishop of Canterbury, insists again and again on the symbolic figure of thalamus Dei in several hymns in honor of the Virgin Mary. So in one of them he points out:

Mary, thalamus of God,

Ask those who venerate you

May they shine with the virtues,

Who are obscured by their sins. ${ }^{44}$

And in another stanza of the same Marian hymn, the prelate of Canterbury proclaims:

Hail, mother of the lawyer [Christ],

Who, happy with the advice,

Left the hall of the incorrupt belly

As of his bridal chamber. ${ }^{45}$

And in another stanza of that hymn St. Anselm insists:

Hail, from whose virginal

Thalamus God proceeds,

Offering himself to us as a dowry

In the betrothal. ${ }^{46}$

A few verses later, the author continues his praise to the Virgin in these terms:

Hail, mother whose husband

And creator and son,

Is God, enlightenment,

Salvation and protection. ${ }^{47}$

Finally, some stanzas later, St. Anselm rounds his praises to Mary as God's nuptial bed:

Hail, that peaceful Zion,

In which the hymn suits God,

Who made for himself a thalamus

\footnotetext{
44،"Maria Dei thalamus,

Posce te venerantibus

Virtutibus ut splendeant,

Quos reatos obtenebrant." (Anselmus Cantauriensis, Hymni et Psalterium De Sancta Virgine Maria. Hymnus ad nocturnum. PL 158, 1035).

45، Ave mater advocati,

Qui beatus consilio,

Aula ventris incorrupti

Processit ex thalamo." (Anselmus Cantauriensis, Hymni et Psalterium De Sancta Virgine Maria. Psalterium Dominae nostrae. Pars I. PL 158, 1037).

46، Ave, cujus virgíneo

Deus processit thalamo,

Dotali nobis gratia

Se praebens in sponsalia.” (Ibid.).

47،"Ave mater cujus sponsus

Et creator et filius,

Deus illuminatio,

Salus est et protectio." (Ibid., 1039).
} 
The hall of your virginity. ${ }^{48}$

About three decades later, the Benedictine abbot Geoffroi de Vendôme (c. 1070-1132), in a sermon on the Nativity of Jesus, points out that Mary was a holy virgin before childbirth, and an even more holy virgin in childbirth, and most holy virgin after childbirth, because the greater the divine intervention was in her, the more holiness and religion grew in her. ${ }^{49}$ And shortly after the author asserts that the door of the womb of Mary was never open, but always closed and sealed, through which God Himself became man, as the husband coming from his nuptial chamber; for this reason the Virgin Mary's womb is called thalamus, because in it the divinity is united with our human flesh, and our flesh with the divinity. ${ }^{50}$

Some years later the illustrious German monk and polygraph Honoré d'Autun (c. 1080-c. 1157) says that the Virgin Mary is the tabernacle of the Church or of God, as said by Psalm 18 "In the sun he put his tabernacle", in which God the Son rested when he came as a man, and from which he came out as a husband comes out from his bridal chamber. ${ }^{51}$

About the same years, the influential Cistercian abbot St. Bernard of Clairvaux (1090-1153), in a sermon for Advent, points out that it is evident that the Virgin Mary is the royal road through which the Savior arrives, coming from his womb as the husband from his nuptial room; that is why he asks Mary to have access to her Son through her, in order to receive Him who was given to us by her. ${ }^{52}$

And in another writing in honor of the Virgin, St. Bernard expresses on the Annunciation:

How much dignity of God! How much excellence of the Virgin! Run, mothers, run, daughters, run all that after Eve, and as a consequence of Eve, and give birth sadly, and give birth. Go to the virginal thalamus [Mary], enter, if you can, in your sister's chaste [bridal] room. ${ }^{53}$

About three decades later the Benedictine monk Pierre de Celle (c. 1115-1183), bishop of Chartres, in a book on the loaves of bread, establishes a suggestive series of analogies between the bread oven, the thalamus, the temple and the Virgin Mary's womb. He begins by saying that Mary is not only an oven, by receiving the Holy Spirit, but also a thalamus, by conceiving God the Son, and also a temple for living chastely; it is an oven, for conversing with total dignity; and a thalamus, by conceiving ineffably; and a temple, by offering herself to God as a living and holy host; and it is an oven to prepare the bread (of the Eucharist), and it is a thalamus to receive the Husband (Christ), and it is a

\footnotetext{
48،"Ave Sion illa pacis,

In qua decet hymnus Deum,

Aulam tuae castitatis

Qui sibi fecit thalamum." (Ibid., 1.041).

49 "Virgo etenim sancta fuit ante partum, et in partu virgo sanctior, et sanctissima virgo post partum, quia quanto majora egit in ea divina operatio, tanto major in ipsa sanctitas crevit atque religio." (Goffridus Vindocinensis, Sermo IV. In Nativitate Domini IV. PL 157, 250).

${ }^{50}$ "Nunquam itaque aperta, sed clausa semper et sigillata fuit uteri matris nostri Salvatoris janua, per quam exivit ipse Deus homo, tamquam sponsus procedens de thalamo (Psal. XVIII, 6). Uterus bonae et beatae virginis Mariae thalamus dicitur, quia in eo sociata sunt et divinitas carni, et caro nostra divinitati." (Ibid.).

51،"Tabernaculum Ecclesiae vel Dei est beata Semper virgo Maria, ut dicitur: In sole posuit tabernaculum suum (Psal, XVIII, 6). In quo Filius Dei homo veniens requievit, et de quo ut sponsus de thalamo processit (ibid.).” (Honorius Augustodunensis, Sigillum Beatae Mariae ubi exponuntur Cantica Canticorum. PL 172, 498).

52،'Sed iam advertistis, ni fallor, quoniam Virgo regia ipsa est via, per quam Salvator advenit, procedens ex ipsius utero, tamquam sponsus de thalamo suo. [...] Per te accessum habeamus ad Filium, o benedicta inventrix gratiae, genitrix vitae, mater salutis, ut per te suscipiat nos qui per te datus est nobis." (Bernardus Claraevallensis, In Adventu Domini. Sermo Secundus, 5. In Obras completas de San Bernardo. Edición bilingüe promovida por la Conferencia Regional Española de Abades Cistercienses, Vol. III. Sermones litúrgicos $\left(1^{\circ}\right)$, Madrid: La Editorial Católica, 1985, 74-76).

53،"Quanta dignatio Dei! Quanta Virginis excellentia! Currite matres, currite filiae, currite omnes, quae post Evam, et ex Eva, et parturimini cum tristitia, et parturitis. Adite virginalem thalamum, ingredimini, si potestis, pudicum sororis vestrae cubiculum." (Bernardus Claraevallensis, In laudibus Virginis Matris. Homilia II. In Obras completas de San Bernardo. Edición bilingüe. Promovida por la Conferencia Regional Española de Abades Cistercienses. Tomo II. Tratados (2º, Madrid: La Editorial Católica, 1984, 615).
} 
temple to introduce the pontiff (Christ). ${ }^{54}$ And then Pierre de Celle goes deeper into the poetic possibilities of these three symbols alluding to the Virgin Mary, while adding:

An oven to feed the hungry, a thalamus to [get] the offspring of Christians, a temple to clean up crimes. An oven to support life, a thalamus for the joy of the embrace, a temple for the dedication of the new life. The Holy Spirit lights the oven, fertilizes the thalamus, consecrates the temple; like fire in the oven, like Husband in the thalamus, like priest in the temple; in the oven the bread is cooked, in the thalamus the uterus is impregnated, in the temple the Most High is pacified. A new bread comes out of the oven, a new progeny is generated in the thalamus, a renewed mob comes from the temple. ${ }^{55}$

And immediately, always in metaphorical reference to the Virgin Mary, the aforementioned bishop continues:

The oven does not burn with the burning of lust; the thalamus is not corrupted or violated with manly pollution, the temple is not desecrated with the splatter of infidelity. In the oven we overheat, in the thalamus we reach puberty, in the temple we grow old with a new birth; the millers are alert near the oven, the virgins watch near the thalamus, the singers are attentive next to the temple. There is work in the oven, rest in the thalamus, songs in the temple. Let's go from the oven to the thalamus, and from the thalamus to the temple. The oven is exposed in public, the thalamus is secretly relocated, the temple is superimposed on top. The Virgin Mary is an oven in her marriage to Joseph, is a thalamus in her impregnation by the Holy Spirit, and is a temple at the birth of her [divine] Son. ${ }^{56}$

Almost six decades later, the cleric and poet Pierre de Blois (1135-1204) in his Sermon 38 on the Birth of Mary says that she is the thalamus of God the Son because of communion in human nature, and Christ was born of her as the husband from his thalamus. ${ }^{57}$

About seven decades later the influential Franciscan theologian and mystic St. Bonaventure of Bagnoregio (1221-1274), known as the Seraphic Doctor (Doctor Seraphicus), in a sermon on the Virgin's Purification, asserts that allegorically we understand the Mary's virginal womb as a temple, in which all the Divinity dwelt bodily: therefore, this uterus is aptly called the temple of God, manufactured by the divine power, adorned by the divine wisdom, dedicated by the divine grace and full of the divine presence. ${ }^{58}$ The author explains such symbolism arguing that the fabrication of that temple is due to the power of God the Father; his ornament, to the wisdom of God the Son; his

\footnotetext{
${ }^{5466 V i r g o, ~ i n q u a m, ~ h a c ~ n o n ~ s o l u m ~ c l i b a n u s ~ e s t, ~ S p i r i t u m ~ s u s c i p i e n d o, ~ s e d ~ t h a l a m u s, ~ D e u m ~ c o n c i p i e n d o, ~}$ templum quoque caste vivendo. Clibanus est, prorsus digne conversando; thalamus ineffabiliter concipiendo; templum, hostiam vivam, sanctam, Deo placentem se offerendo. Clibanus ad panem praeparandum; thalamus, ad Sponsum excipiendum; templum ad pontificem intromittendum." (Petrus Cellensis, Liber de Panibus, cap. XXI. PL 202, 1018).

${ }^{55}{ }^{\circ} \mathrm{C}$ Clibanus ad victum esurientium; thalamus ad sobolem Christianorum, templum ad emundationem delictorum. Clibanus vitae sustentationem, thalamus amplexus jucunditatem, templum ad novae vitae dedicationem. Clibanum inflammat Spiritus sanctus, thalamum fecundat, templum consecrat; ignis in clibano, Sponsus in thalamo, sacerdos in templo; in clibano panis decoquitur, in thalamo uterus impraegnatur, in templo Altissimus pacificatur. Panis novus a clibano, nova progenies a thalamo, plebs renovata procedit a templo." (Ibid.).

56“Non ardet clibanus libidinis ardore; non corrumpitur vel violatur thalamus virili contaminatione, non profanatur templum infidelitatis conspersione. In clibano recalescimus, in thalamo pubescimus, in templo nativitate bona senescimus; pistores circa clibanum, virgines circa thalamum, cantores excubant ad templum. Labor in clibano, quies in thalamo, cantus in templo. A clibano ad thalamum, a thalamo ad templum properamus. In publico exponitur clibanus, in abscondito reponitur thalamus, in excelso templum superponitur. Clibanus est Virgo in Joseph desponsatione, thalamus in Spiritus impraegnatione, templum in Filii nativitate." (Ibid.).

57،"Thalamus est propter naturae communionem, de quo Christus egressus est tamquam sponsus de thalamo suo". (Petrus Blesensis. Sermo XXXVIII. In Nativitate Beatae Mariae. PL 207, 675).

58،"Secundum allegoriam vero nomine templi datur intelligi uterus Virginis, in quo tota Divinitas corporaliter habitavit; et ideo recte dicitur Dei templum fabricatum divina potentia, adornatum divina sapientia, dedicatum divina gratia et adimpletum divina praesentia." (Bonaventura de Balneoregio, Sermones de B. Virgine Maria. I. De Purificatione B. Virginis Mariae. Sermo III. In Obras de San Buenaventura. Tomo IV. Teología mística, Madrid: La Editorial Católica, 1963, p. 564).
} 
dedication, to the grace of the Holy Spirit, and his full completion, to the presence of the incarnate Word. Because, being "the noble triclinium of the entire divine Trinity," it is, however, a special temple and abode of the Incarnate Word of God. ${ }^{59}$

And, in a sermon on the Annunciation, St. Bonaventure claims that the Creator of the universe rested in the tabernacle of the virginal womb, for having put his bridal chamber there to become our brother, for having prepared there the royal throne to become our prince, for having taken the priestly ornaments to become our Pontiff. The author argues that, by this nuptial union, the Virgin Mary is the Mother of God; by the royal throne, she is the Queen of heaven; and by the priestly ornaments, she is the lawyer of Mankind; and for all that the Virgin Mary was perfectly suitable, being as she was of human race, of royal lineage and of priestly lineage; therefore she can say with property: The one who gave me the being rested in my tabernacle.$^{60}$ And soon after the Seraphic Doctor insists:

In her [womb of Mary, God the Son] set his bridal chamber for himself; and he did this precisely to marry human nature in the virginal womb, which was anticipated, through the divine Spirit, by the prophet David when saying with prophetic certainty: He put his tabernacle in the sun. In the sun, he says, that is, in the Holy Virgin, correctly called the sun, for she was clothed with the sun and filled with the light of eternal clarity, according to the chapter 12 of Apocalypse: A woman clothed with the sun, and the moon under his feet. ${ }^{61}$

To complete his reasoning, St. Bonaventure adds:

So, rightly, he says: In the sun, that is, in the blessed Virgin [Mary]. And then she adds as a husband, because the Virgin's womb was the thalamus in which God [the Son] joined human nature, and hugging it, united himself to it with a nuptial bond. [...] In this [...] sacrosanct uterus God the Son introduced human nature, to marry it, and so that our Creator of the universe became our brother, and the blessed Virgin became the Mother of all Saints. ${ }^{62}$

Already in the 15th century St. Lawrence Justinian (1381-1456), patriarch of Venice, states that the Word of God, Christ, is the husband, the flesh or human nature is the wife, and the womb of the Virgin is the thalamus, in which and from which the divine Word was made man in order to dwell among us, as David sang it in the Psalm, saying: In the sun he put his tabernacle, and he himself as a husband from his thalamus. That is why the Venetian prelate concludes that this thalamus is deservedly chosen, in which the divine mysteries are celebrated, since the Virgin Mary was "a clean thalamus for her purity, ornamented with good customs and endowed with all sanctity, irrigated by all flowers, decorated with virtues, fragrant with the smell of chastity, fervent of charity, exhaling of virginity, powerful of humility." 63

\footnotetext{
59،Debetur enim huius templi fabricatio potentiae Patris; adornatio, sapientiae Filii; dedicatio, gratiae Spiritus sancti; adimpletio, praesentia Verbi incarnati. Cum enim sit 'totius Trinitatis nobile triclinium', est tamen Verbi incarnati speciale templum et hospitium." (Ibid.).

60،"Propter nuptiale connubium Virgo Maria est Mater Dei; propter regale solium, regina caeli; propter sacerdotale ornamentum, advocata generis humani. Et ad haec omnia idonea erat Virgo Maria, cum esset de genere hominum, de genere regum et de genere sacerdotum. Dicat ergo amantissima Virgo Maria: Qui creavit me requievit in tabernaculo meo." (Bonaventura de Balneoregio, Sermones de B. Virgine Maria. II. De Annunciatione B. Virginis Mariae. Sermo IV. In Obras de San Buenaventura. Tomo IV. Teología mística, Madrid: La Editorial Católica, 1963, 628-631).

61'In quo statuit sibi cubiculum nuptiale; et hoc quidem fecit, ut humanam naturam sibi in virginali utero desponsaret, quod praevidens in Spiritu, dicebat prophetica certitudine propheta David: In sole posuit tabernaculum suum. In sole, dicit, id est in beata Virgine, quae recte sol dicitur, quia amicta fuit sole et impleta lumine claritatis aeternae, secundum illud Apocalypsis duodecimo: Mulier amicta sole et luna sub pedibus eius". (Ibid.).

62"'Recte ergo dicit: In sole, hoc est in beata Virgine. Et post subditur tanquam sponsus, quia Virginis uterus thalamus fuit, in quo naturae humanae coniunctus est Deus, et eam deosculans, nuptiali est sibi foedere copulatus. [...] In hoc [...] sacrosanctum uterum, introduxit Dei Filius humanam naturam, ut eam sibi desponsaret, et omnium Creator noster fieret frater, et beata Virgo efficeretur omnium Sanctorum mater.” (Ibid.).

63،"Verbum sponsus, caro sponsa, Virginis uterus thalamus, in quo factum est et de quo egressum est, ut habitaret in nobis. Hoc exprimere citharoeda sanctus voluit quum in psalmo caneret dicens: in sole posuit tabernaculum suum, et ipse tamquam sponsus procedens de thalamo suo. Merito talis eligitur thalamus, in quo divina celebrentur mysteria. Erat quidem beata Virgo thalamus puritate nitidus, moribus ornatus et omni praeditus sanctitate, floribus aspersus, virtutibus decoratus, fragrans castitatis odore, caritate fervens, virginitate redolens, pollens humilitate." (Laurentius Justinianus, quoted by Passaglia, 1856, 581).
} 
The Symbol of Bed (Thalamus) in Images of the Annunciation of the 14th-15th Centuries in the Light of Latin Patristics

\section{CONClusions}

At the end of this double research through images and texts, six essential conclusions seem to be imposed

- The bed (thalamus) is a piece of furniture included quite frequently and with clear prominence (almost always with large dimensions, and in the center of the scene) in some images of the Annunciation of the 14th and 15th centuries.

- Such a frequent and prominent presence of the bed in these Annunciations reveals that it contains some important doctrinal symbolism.

- Almost all art historians who analyze these very special Annunciations forget to mention the bed; and, when they mention it, they fail to understand or, at least, do not justify the different and deep doctrinal meanings of this bed.

- Based on the solid and coherent patristic and theological tradition -illustrated in this article only by the Latin Patristics-, we can interpret the bed in the Annunciations of the 14th and 15th centuries according to a double and complementary dogmatic symbolism, simultaneously Mariological and Christological

- The Latin Fathers and theologians consulted agree to consider the Virgin Mary - more specifically, her virginal womb - as the metaphorical "bed or nuptial chamber of God" (thalamus $D e i)$, in a double sense, namely the womb of Mary is: a) the nuptial bed in which God the Son marries his virgin Mother; b) the nuptial bed in which God the Son, incarnate, "marries" his divine nature with human nature.

- Based on these textual metaphors around the bed or nuptial chamber, brought to light by the multisecular and multiple patristic and theological tradition, the intellectual authors of these images of the Annunciation of the 14nth and 15th centuries include in them with evident prominence a bed, with the purpose of illustrating, as a visual metaphor, two complementary dogmas: a) the substantial union of the two natures, divine and human, in the unique person of Christ, God the Son made man; b) the virginal divine maternity of Mary.

\section{REFERENCES}

[1] Ambrosius Mediolanensis, Hymnus IV. PL 16, 1.410-1.411.

[2] Anselmus Cantauriensis, Hymni et Psalterium De Sancta Virgine Maria. Hymnus ad nocturnum. PL 158, 1.035-1.049.

[3] Bernardus Claraevallensis, In Adventu Domini. Sermo Secundus, 5. In Obras completas de San Bernardo. Edición bilingüe promovida por la Conferencia Regional Española de Abades Cistercienses, vol. III. Sermones litúrgicos $\left(1^{\circ}\right)$, Madrid: La Editorial Católica, 1985, 74-76.

[4] Bernardus Claraevallensis, In laudibus Virginis Matris. Homilia II. In Obras completas de San Bernardo. Edición bilingüe. Promovida por la Conferencia Regional Española de Abades Cistercienses, Tomo II. Tratados $\left(2^{\circ}\right)$. Madrid: La Editorial Católica, 1984, p. 615.

[5] Bonaventura de Balneoregio. I. De Purificatione B. Virginis Mariae. Sermo III. In Obras de San Buenaventura. Edición bilingüe. Vol. IV. Teología mística. Madrid: La Editorial Católica, 1963, 563-567.

[6] Bonaventura de Balneoregio. Sermones de B. Virgine Maria. II. De Annunciatione B. Virginis Mariae. Sermo IV. In Obras de San Buenaventura. Tomo IV. Teología mística. Madrid: La Editorial Católica, 1963, 628-631.

[7] Goffridus Vindocinensis, Sermo IV. In Nativitate Domini IV. PL 157, 250.

[8] Hildefonsus Toletanus, Liber de virginitate perpetua S. Mariae adversus tres infideles, III. PL 96, 66-67.

[9] Honorius Augustodunensis, Sigillum Beatae Mariae ubi exponuntur Cantica Canticorum. PL 172, 495518.

[10] Isidorus Hispalensis, De fide Catholica contra Judaeos. Liber Primus, X, 10. PL 83, 470.

[11] Maximus Taurinensis, Sermo 42, 5. PL 57, 738-739.

[12] Petrus Blesensis. Sermo XXXVIII. In Nativitate Beatae Mariae. PL 207, 672-677.

[13] Petrus Cellensis, Liber de Panibus, XXI. PL 202, 929-1.046.

[14] Petrus Chrysologus, Sermo CXLI. De Incarnatione Domini. PL 52, 577-588. 
The Symbol of Bed (Thalamus) in Images of the Annunciation of the 14th-15th Centuries in the Light of Latin Patristics

[15] Petrus Damianus, Carmina et preces. XVI. In eadem annuntiatione beatissimae virginis Mariae. Ad missam, Praefatio. PL 145, 934.

[16] Petrus Damianus, Sermo XLV. II. In Nativitate Beatissimae Virginis Mariae. PL 144, 740-748.

[17] Venantius Fortunatus, Miscellanea. Liber VIII. Caput VI. In nomine Domini nostri Jesu Christi et Domnae Mariae Matris eius de virginitate. PL 88, 268-269.

[18] Venantius Fortunatus, Miscellanea. Liber VIII. Caput VII. In laudem sanctae Mariae Virginis et matris Domini. PL 88, 276-284.

[19] Châtelet, A. (1999a). Rogier van der Weyden (Rogier de le Pasture). Paris : Gallimard.

[20] Châtelet, A. (1999b). Rogier van der Weyden. Problèmes de la vie et de l'ouvre. Strasbourg: Presses Universitaires de Strasbourg.

[21] Davis, M. (1973). Rogier van der Weyden. Essai accompagné d'un catalogue critique des oeuvres qui lui ont été attribuées ainsi qu'à Robert Campin. Bruxelles : Arcade.

[22] Delenda, O. (1987). Rogier van der Weyden (Roger de Le Pasture). Paris: Cerf, Tricorne.

[23] De Vos, D. (1999). Rogier van der Weyden. L'cuvre complet. Paris: Hazan.

[24] Friedländer, M. J. (1967 [1924]), Early Netherlandish painting. Vol. 2, Rogier van der Weyden and the Master of Flemalle. Leiden: A.W. Sijthoff

[25] Glossi, G. \& Princi, E. (2011 [1989]). Filippo e Filippino Lippi. Firenze: Scala.

[26] Hodne, L. (2015). “Light Symbolism in Gentile da Fabriano’s Vatican Annunciation”. Eikón Imago, 6, 2015 / 2: 33-50.

[27] Holmes, M. (1999). Fra Filippo Lippi. The Carmelite painter. New Haven: Yale University Press.

[28] Kemperdick, S. \& Sander, J. (ed.). (2009). The Master of Flémalle and Rogier van der Weyden (exhib. cat.), Städel Museum, Frankfurt am Main, and the Gemäldegalerie, Staatliche Museen, Berlin, Ostfildern, Hatje Cantz.

[29] Lightbown, R. (1989). Botticelli. Life and work. London: Thames and Hudson.

[30] Marchini, G. (1979). Filippo Lippi, Milano: Electa.

[31] Panofsky, E. (1966 [1953]). Panofsky, Erwin, Early Nederlandish painting. Its origins and character. Cambridge, Mass.: Harvard University Press.

[32] Pazos López, Á. (2019). "La aparición de las vestiduras litúrgicas del cristianismo occidental en la iconografía tardoantigua y altomedieval". De Medio Aevo, 13, 241-248.

[33] Philippot, P. (1994). La peinture dans les anciens Pays-Bas: XVe-XVIe siècles, Paris: Flammarion.

[34] Poeschke, J. (2003). Fresques italiennes du temps de Giotto, 1280-1400. Paris: Citadelles \& Mazenod.

[35] Ruda, J. (1993). Fra Filippo Lippi. Life and Work with a Complete Catalogue. New York: Harry N. Abrams.

[36] Salvador-González, J.M. (2012). Ancilla et Regina. Aproximaciones a la iconografía mariana en la Edad Media, Saarbrücken: Editorial Académica Española.

[37] Salvador-González, J.M. (2013). Flos de radice Iesse. A hermeneutic approach to the theme of the lily in the Spanish Gothic painting of The Annunciation from patristic and theological sources". Eikón Imago, 4: 183-222.

[38] Salvador-González, J.M. (2014a). "In virga Aaron Maria ostendebatur. Nueva interpretación del lirio en La Anunciación gótica española a la luz de fuentes patrísticas y teológicas", Anales de Historia del Arte, 24, 37-60.

[39] Salvador-González, J.M. (2014b), "Flos campi et lilium convallium. Third interpretation of lily in the iconography of The Annunciation in Italian Trecento art from patristic and theological sources", Eikón Imago, 5, 75-96.

[40] Salvador-González, J.M. (2015a). "The Virgin Mary as a model of obedience in the patristic tradition and her representation in the late medieval iconography of the Annunciation", Oxford Academic Studies Press. Social Sciences and Humanities Journal, vol. 10, \# 8, 2-23.

[41] Salvador-González, J.M. (2015b). "Per aurem intrat Christus in Mariam. Aproximación iconográfica a la conceptio per aurem en la pintura italiana del Trecento desde fuentes patrísticas y teológicas". Ilu. Revista de Ciencias de las Religiones, 20, 193-230.

[42] Salvador González, J.M. (2015c), "Sanctitate vernans virga Aaronis. Interpretation of the stem of lilies in the medieval iconography of the Annunciation according to theological sources". Oxford Academic Studies Press. Art Studies and Architectural Journal, vol. 10, \# 9, 2-32. 
[43] Salvador-González, J.M. (2019a). "Iconographic interpretation of the temple as a theological symbol in images of the Annunciation of the 14th and 15th centuries" (article under evaluation in an academic journal).

[44] Salvador-González, J.M. (2019b), "The bed in images of the Annunciation of the 14th and 15th centuries as a doctrinal symbol in the light of Greek Patristics" (article under evaluation in an academic journal).

[45] Schulz, V.-S. (2018). "Infiltrating Artifacts: The Impact of Islamic Art in Fourteenth- and FifteenthCentury Florence and Pisa", Konsthistorisk tidskrift/Journal of Art History, 87:4, 214-233.

\section{AUTHOR BIOGRAPHY}

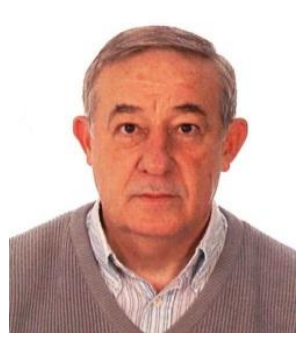

José María Salvador-González, Bachelor of Humanities (Philosophy) at the Complutense University of Madrid (1971), has a PhD in Aesthetics and Art Sciences at the Panthéon-Sorbonne University of Paris (1981), a PhD in Social Sciences at the Central University of Venezuela, Caracas (2002), as well as a $\mathrm{PhD}$ in History of Art (2007) and a PhD in Sciences of Religion (2018), both of them at the Complutense University of Madrid. It also has other Degrees, Masters, Diplomas of Advanced Studies (DEA) at several universities of Rome, Paris, Leuven (Belgium), Madrid and Caracas. Retired Full Professor at the Central University of Venezuela, Caracas, he is today a Professor of Art History at the Complutense University of Madrid. Author of more than forty books and monographs, he has participated with presentations and communications in over forty Conferences, most of them international.

Citation: José María Salvador-González. "The Symbol of Bed (Thalamus) in Images of the Annunciation of the 14th-15th Centuries in the Light of Latin Patristics". International Journal of History and Cultural Studies (IJHCS). vol 5, no. 4, 2019, pp. 49-70 doi: DOI: http://dx.doi.org/10.20431/2454-7654.0504005.

Copyright: () 2019 Authors. This is an open-access article distributed under the terms of the Creative Commons Attribution License, which permits unrestricted use, distribution, and reproduction in any medium, provided the original author and source are credited. 